\title{
Genetic and Environmental Predisposing Factors of Autism Spectrum Disorders
}

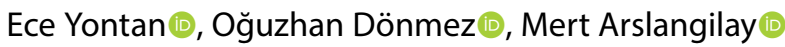

In 1943, Dr. LeoKanner introduced the terminology of medicine to the word autism. ${ }^{[1]}$ Autism spectrum disorder (ASD) is a complex developmental condition with persistent difficulties in social interaction, speech, nonverbal communication and repetitive behavior. The effects of ASD and the severity of symptoms vary in every person. Most symptoms of ASD usually occur in children aged about 2 to 3 years and are usually diagnosed at these ages. Until they start to walk, some children with ASD will normally stop developing skills and lose what they have previously gained. According to a worldwide study by the US Department of Health, one in 59 children has autism spectrum disorder. Autism spectrum disorder is three to four times more common in boys than in girls, and many girls with ASD show less prominent signs than boys. ${ }^{[2]}$

Symptoms of Asperger syndrome, one of the autism spectrum disorders described by Doctor Hans Asperger, are usually manifested at older ages, unlike other autism spectrum disorders, and, unlike the general indicators of autism, there is no developmental retardation in speech and language skills. As it can be understood, ASD is two-way. Such that; a number of recent studies have reported a positive genetic correlation between autism and

Biruni University Medicine, Istanbul, Turkey

Correspondence: Ece Yontan. Biruni Üniversitesi Tıp Fakültesi, 34010 Zeytinburnu, İstanbul, Türkiye.

E-mail: eceyontan1@gmail.com

Cite this article as: Yontan E, Dönmez O, Arslangilay M. Genetic and Environmental Predisposing Factors of Autism Spectrum Disorders. JEB Med Sci 2020;1(1):18-22.

doi: $10.5606 /$ jebms.2020.75604

Received : July 07,2019

Accepted : December 12, 2019

Published online : April 23, 2020

O2020 Journal of Experimental and Basic Medical Sciences. All rights reserved.

\begin{abstract}
Autism spectrum disorder (ASD) is a complex neurodevelopmental situation with persistent difficulties in social interaction, speech, nonverbal communication and repetitive behavior that can be diagnosed at an early age. In recent years, the increasing number of ASD cases has shifted the interest of science in this direction. According to a worldwide survey, one in every 59 children has autism spectrum disorder. In this article, environmental and genetic factors that cause autism spectrum disorders are discussed. Keywords: Autism spectrum disorder, autistic, biomarkers, serotonin.
\end{abstract}

measures of mental ability. These findings show that the alleles of ASD are broadly overlapping with the paradoxical seemingly high-intelligence alleles, which are generally characterized by below-average intelligence quotient (IQ). ${ }^{[3]}$ This paradox can be solved under the hypothesis that the etiology of ASD generally includes components of advanced but unbalanced intelligence. This hypothesis is supported by evidence that autism and high IQ share various convergent correlations such as large brain size, rapid brain growth, increased sensory and visual-spatial abilities, improved synaptic functions, increased attention focus, and high socioeconomic status. ${ }^{[4]}$

Autism spectrum disorder is known to be a multifactorial syndrome. In addition to environmental causes, genetic causes have recently been found (Table 1, 2). ${ }^{[4]}$

\section{ETIOLOGICAL FACTORS AND GENETIC DISEASES WITH AUTISM SPECTRUM DISORDER ${ }^{[5]}$}

\section{Are there any ASD Genes?}

The increased prevalence of genetic testing has allowed exploration of relationships between 


\begin{tabular}{l} 
Table 1. Etiological factors \\
\hline Genetic diseases \\
Natal factors \\
Neuroanatomic factors \\
Neurochemical factors \\
Immune factors \\
Genetic factors \\
Environmental factors \\
\hline
\end{tabular}

\section{Table 2. Genetic diseases with autism}

Fragile $\mathrm{X}$ syndrome

Tuberous sclerosis

Phenylketonuria

Williams syndrome

Cornelia de Lange syndrome

Joubert syndrome

Moebius syndrome

Smith-Lemli-Opitz syndrome

Neurofibromatosis

Sotos syndrome

Hypomelanosis ito

Aarskog syndrome

multiple genes and various neurological disorders. There are 1007 genes identified in the SFARI Gene database for susceptibility to ASD. Several genes have been identified, including the MECP2 and CHD8 genes, which are specific to autism alone. ${ }^{[6]}$ It has been reported that some genes that are found to undergo changes with ASD play an important role in hormonal pathways. ${ }^{[7]}$ The RORA gene, which plays an important role in immunity and neurodevelopment, has been shown to be associated with the level of transcription such as NLGN1 and NTRK2 genes. These genes are also those that encode the catalytic receptors of neurotropins. In addition, the effect of ITPR1 gene on calcium channels has been shown to play an important role in neurodegenerative diseases. The RBFOX1 gene encodes insertions to provide membrane stimulation and synaptic transmission. ${ }^{[8]}$ Studies have shown that there is a relationship between autism and various variants of the OXTR gene. ${ }^{[9]}$

Methylation of the OXTR promoter gene has been found to be associated with the etiology of autism, albeit in small studies. ${ }^{[10]}$ At the same time, transcriptional differences related to hypermethylation of the OXTR gene in the temporal lobe of autistic individuals have been observed. ${ }^{[11]}$ One of the biomarkers investigated in ASD is high serotonin level. ${ }^{[12]}$ The relationship between polymorphism in the serotonin regulator SLC6A4 gene and psychiatric diseases has been reported. ${ }^{[13]}$ SLC6A4 gene expression was found to be lower in individuals with autism. Therefore it is thought that there is a lack of serotonin reuptake. ${ }^{[14]}$ Mutations in the RELN gene in ASD may result in decreased expression of the reel. It is thought that expression changes resulting from hypermethylation of the promoter region of the RELN gene or mutations by an unknown mechanism may be associated with neuropsychiatric diseases. ${ }^{[15]}$ When RELN polymorphism was compared to healthy controls in individuals with ASD, it was reported that rs 1270519 polymorphism was found to be statistically significant compared to healthy controls, whereas no significant difference was found between rs362691 in the two groups. ${ }^{[16]}$

The methylenetetrahydrofolatreductase (MTHFR) enzyme is an important enzyme in folate metabolism. The MTHFR gene is localized on chromosome 1p36.3. MTHFR converts 5,10 methylenetetrahydrofolate (5,10-methylene THF) irreversibly to 5-methyl tetrahydrofolate (5-methyl THF). ${ }^{[17]}$

Since the enzyme will be inactive when the MTHFR gene is mutated, it causes hyperhomocysteinemia and homocysteinuria, which is an important risk factor for cardiovascular and cerebrovascular diseases. ${ }^{[18]}$

Two polymorphisms have been reported in the MTHFR gene, C677T (rs1801133) and A1298C (rs1801131). ${ }^{[19]}$

Based on this information, it has been reported that MTHFR gene may play an important role in the pathophysiology of autism. ${ }^{[20]}$

SHANK3 is a member of the family of structural proteins located at the center of the postsynaptic density of the excitatory glutamergic neurons. It acts as the main regulator of glutamergic synapses. ${ }^{[21]}$ The incorporation of SHANK3 into actin nucleation and the association of variant $\mathrm{S} 685 \mathrm{I}$ with OSB shows that actin nucleation plays a critical role in the pathogenesis of SHANK3 deficiency. ${ }^{[22]}$

Nowadays, although genetics of autism is widely discussed and researched, it opens the door to new research. In the context of autism and genetics, many genes are suspected to be associated with autism. Especially according to candidate gene studies, hundreds of genes are responsible for autism, especially NRXN1, SHANK3, NLGN3, NLGN4, MeCP2, 


\begin{tabular}{ll} 
Table 3. List of genes associated with ASD & {$[23]$} \\
Chromosome & Known genes \\
2 & NRXN1, SCN7A \\
3 & GAT1, OXTR, CNTN3, SLC9A9, D1A1 \\
7 & FOXP2, WNT2, RELN, HOXA1, HOXB1, MET, EN2 \\
11 & HRAS \\
15 & GABRB3, GABRA5, GABRG3, UBE3A, ATP10C \\
17 & 5-HTT \\
22 & SHANK3 \\
$X$ & MeCP2, NLGN3, NLGN4, SLC9A6, FMR1 \\
\hline
\end{tabular}

EN2, CNTNAP2, OXTR, RELN, GABRB3, GABRA5, GABRG3 (Table 3). ${ }^{[23]}$

\section{ENVIRONMENTAL FACTORS CAUSING} ASD

Although genetics play a major role in the pathophysiology of ASD, the impact of environmental factors is considerable. ${ }^{[24]}$

\section{Abnormal melatonin synthesis}

Melatonin is an endogenous neurohormone produced predominantly in the pineal gland in the dark and levels of melatonin or melatonin derivatives in individuals with ASD are generally found to be below average. ${ }^{[24]}$ Circadian abnormalities in autism may be the result of genetic abnormalities related to melatonin synthesis. Deletions of the ASMT (acetylserotonin O-methyltransferase) gene encoding the last enzyme of melatonin synthesis have been found in several individuals with ASD. ${ }^{[25]}$ In addition, environmental factors may affect melatonin synthesis. For example, maternal stress has been shown to cause lower melatonin levels. ${ }^{[26]}$

\section{Zinc deficiency}

The balance of metal ions in our bodies is essential for the brain to function correctly and when this balance is broken, neurological symptoms are inevitable. Since zinc, which is one of these ions, plays a major role in cell division and differentiation, its deficiency will make significant changes in neurological functions. ${ }^{[27]}$ It is so clear that zinc supplements are used in nutritional therapy in autistic patients. ${ }^{[28]}$

\section{Maternal diabetes}

Meta-analysis studies showing that exposure of the embryo/fetus to pregnancy complications may increase the risk of autism has shown that maternal diabetes during pregnancy increases the risk of autism twice. ${ }^{[29]}$ The pathophysiology of this process; maternal-hyperglycinemia, fetal hyperinsulinemia and increased maternal-placenta-fetus insulin-like growth factors have been identified in recent years. ${ }^{[30]}$

\section{Foods and intestines}

The main problem with autism is in the brain, but some other organs may also have some effect on autism. The most important representative of these organs is the intestine. The reasons for the recent focus on the brain-intestinal-behavior axis are; Twoway partnership showing intestinal and behavioral findings, possible relationship between diet-GISautism, and bowel microbiota collection related to autism. For now, information on this subject is limited, but scientific studies are ongoing. ${ }^{[31]}$

\section{PRENATAL AND PERINATAL STRESS FACTORS}

Occurring in the mother; Immune changes such as lymphocyte proliferation, natural killer cell activity, and decrease in cytokines may reduce viral resistance. It was thought that pathological mechanisms that may arise with this decrease may increase the risk of autism. ${ }^{[32]}$ The effect of prenatal stress on postnatal HPA (hypothalamus, pituitary, adrenocortical system), ACS (acute coronary syndrome) reactivity and stress hypersensitivity have been reported to be associated with autism in some studies. ${ }^{[33]}$ It has been reported that autism is more common in men than in women. Therefore it is thought that high levels of testosterone exposure during critical periods of pregnancy may increase the risk of autism. ${ }^{[34]}$

\section{PARENT AGE}

In a meta-analysis study involving 25,687 ASD cases and 8,655,576 control groups, advanced maternal age was considered to be among the factors increasing the risk of autism. Studies related to father age are ongoing. The mechanisms of advanced maternal and paternal age being risk factors are different. Small-scale de-novo mutations accumulate mostly in fathers. These are associated with advanced parental age. ${ }^{[35]}$ In addition, advanced maternal age may be a risk factor for autism with increasing pregnancy complications. ${ }^{[36]}$ However as shown in the tables, there is no statistically significant difference (Table 4). ${ }^{[29]}$ 


\section{Tablo 4. OSB ve ebeveyn yaşı değerlendirilmesi ${ }^{[33]}$}

\begin{tabular}{|c|c|c|c|}
\hline & \multicolumn{2}{|c|}{ Evaluation of mothers' age } & \multirow[b]{3}{*}{$p$} \\
\hline & Severe ASD & Average-mild & \\
\hline & Mean $\pm S D$ & Mean $\pm S D$ & \\
\hline Maternal age & $34.1 \pm 3.9$ & $33.6 \pm 5.8$ & 0.682 \\
\hline
\end{tabular}

\begin{tabular}{|c|c|c|c|}
\hline & \multicolumn{2}{|c|}{ Evaluation of father' age } & \multirow[b]{3}{*}{$p$} \\
\hline & Severe ASD & Average-mild & \\
\hline & Mean \pm SD & Mean $\pm S D$ & \\
\hline Father age & $36.5 \pm 3.5$ & $36.7 \pm 5.40$ & 0.888 \\
\hline
\end{tabular}

SD: Standard deviation.

\section{Prenatal infections}

Maternal immunoglobulin G (IgG) antibodies that occur during infections during pregnancy and targeted to the brain of the fetus are claimed to be pathogenic in some ASD cases. Studies have reported that Rubella infection of the mother during pregnancy may cause ASD in the baby. Congenital Rubella infection has been reported to occur in approximately 4 to $7 \%$ of ASD cases. In a study comparing brain tissues of individuals with autism and brain tissues of control groups, Epstein-Barr virus, Herpes Simplex type 1 and type 2 virus, JC virus, citomegalovirus, BK virus, Herpes Simplex type 6 viruses were reported to be more common in individuals with autism. ${ }^{[37]}$

In conclusion, although autism spectrum disorders have many genetic and environmental predisposing factors, it would not be correct to conclude that one or more of these disorders are strictly related.

\section{Declaration of conflicting interests}

The authors declared no conflicts of interest with respect to the authorship and/or publication of this article.

\section{Funding}

The authors received no financial support for the research and/or authorship of this article.

\section{REFERENCES}

1. Kanner L. Autistic disturbances of affective contact. Nerv Child 1943;2:217-50.

2. American Psychiatric Association, 2018.

3. Hippler $\mathrm{K}$, Klicpera C. A retrospective analysis of the clinical case records of 'autistic psychopaths' diagnosed by Hans Asperger and his team at the University Children's Hospital, Vienna. Philos Trans R Soc Lond B Biol Sci 2003;358:291-301.

4. Crespi BJ. Autism as a disorder of high intelligence. Front Neurosci 2016;10:300.
5. Yüksel A. Otizm genetiği. Cerrahpaşa Tıp Dergisi 2005;36:35-41.

6. Guo H, Peng Y, Hu Z, Li Y, Xun G, Ou J, et al. Genomewide copy number variation analysis in a Chinese autism spectrum disorder cohort. Sci Rep 2017;7:44155.

7. Sarachana T, Hu VW. Genome-wide identification of transcriptional targets of RORA reveals direct regulation of multiple genes associated with autism spectrum disorder. Mol Autism 2013;4:14.

8. Salehi M, Kamali E, Karahmadi M, Mousavi SM. RORA and Autism in The Isfahan Population: Is There An Epigenetic Relationship. Cell J 2017;18:540-6.

9. Ebstein RP, Knafo A, Mankuta D, Chew SH, Lai PS. The contributions of oxytocin and vasopressin pathway genes to human behavior. Horm Behav 2012;61:359-79.

10. Kumsta R, Hummel E, Chen FS, Heinrichs M. Epigenetic regulation of the oxytocin receptor gene: implications for behavioral neuroscience. Front Neurosci 2013;7:83.

11. Jack A, Connelly JJ, Morris JP. DNA methylation of the oxytocin receptor gene predicts neural response to ambiguous social stimuli. Front Hum Neurosci 2012;6:280.

12. Gabriele $S$, Sacco R, Persico AM. Blood serotonin levels in autism spectrum disorder: A systematic review and meta-analysis. Eur Neuropsychopharmacol 2014;24:919-29.

13. Huang $\mathrm{CH}$, Santangelo SL. Autism and serotonin transporter gene polymorphisms: a systematic review and meta-analysis. Am J Med Genet B Neuropsychiatr Genet 2008;147B:903-13.

14. Şener EF, Korkmaz K, Öztop DB, Zararsız G, Özkul Y. Investigation of SLC6A4 gene expression in autism spectrum disorders. JCEI 2015;6:165-9.

15. Fatemi SH, Earle JA, McMenomy T. Reduction in Reelin immunoreactivity in hippocampus of subjects with schizophrenia, bipolar disorder and major depression. Mol Psychiatry 2000;5:654-63.

16. Şahin N, Kara M, Kara B, Topal H. Otizm spektrum bozukluğu olan çocuklarda RELN gen polimorfizminin değerlendirilmesi. Anadolu Psikiyatri Derg 2018;19:599-606.

17. Homberger $A$, Linnebank $M$, Winter $C$, Willenbring $H$, Marquardt $T$, Harms $E$, et al. Genomic structure and transcript variants of the human methylenetetrahydrofolate reductase gene. Eur J Hum Genet 2000;8:725-9.

18. Daly SF, Molloy AM, Mills JL, Lee YJ, Conley M, Kirke PN, et al. The influence of 5,10 methylenetetrahydrofolate reductase genotypes on enzyme activity in placental tissue. Br J Obstet Gynaecol 1999;106:1214-8.

19. Goode EL, Potter JD, Bigler J, Ulrich CM. Methionine synthase D919G polymorphism, folate metabolism, and colorectal adenoma risk. Cancer Epidemiol Biomarkers Prev 2004;13:157-62.

20. Ismail S, Senna AA, Behiry EG, Ashaat EA, Zaki MS, Ashaat NA, et al. Study of C677T variant of methylene tetrahydrofolate reductase gene in autistic spectrum disorder Egyptian children. Am J Med Genet B Neuropsychiatr Genet 2019;180:305-9. 
21. Boeckers TM, Kreutz MR, Winter C, Zuschratter W, Smalla $\mathrm{KH}$, Sanmarti-Vila L, et al. Proline-rich synapse-associated protein-1/cortactin binding protein 1 (ProSAP1/ CortBP1) is a PDZ-domain protein highly enriched in the postsynaptic density. J Neurosci 1999;19:6506-18.

22. Iossifov I, O'Roak BJ, Sanders SJ, Ronemus M, Krumm $N$, Levy $D$, et al. The contribution of de novo coding mutations to autism spectrum disorder. Nature 2014;515:216-21.

23. Şener EF, Özkul Y. Otizmin genetik temelleri. Sağlık Bilimleri Dergisi 2013;22:86-92.

24. Rossignol DA, Frye RE. Melatonin in autism spectrum disorders: a systematic review and meta-analysis. Dev Med Child Neurol 2011;53:783-92.

25. Melke J, Goubran Botros H, Chaste P, Betancur C, Nygren $\mathrm{G}$, Anckarsäter $\mathrm{H}$, et al. Abnormal melatonin synthesis in autism spectrum disorders. Mol Psychiatry 2008;13:90-8.

26. Feng $P, \mathrm{Hu} Y$, Vurbic D, Guo Y. Maternal stress induces adult reduced REM sleep and melatonin level. Dev Neurobiol 2012;72:677-87.

27. Takeda A. Zinc homeostasis and functions of zinc in the brain. Biometals 2001;14:343-51.

28. Babaknejad N, Sayehmiri F, Sayehmiri K, Mohamadkhani A, Bahrami S. The Relationship between Zinc Levels and Autism: A Systematic Review and Meta-analysis. Iran J Child Neurol 2016;10:1-9.

29. Gardener H, Spiegelman D, Buka SL. Prenatal risk factors for autism: comprehensive meta-analysis. Br J Psychiatry
2009;195:7-14.

30. Eidelman Al, Samueloff A. The pathophysiology of the fetus of the diabetic mother. Semin Perinatol 2002;26:232-6.

31. Whiteley P. Food and the gut: relevance to some of the autisms. Proc Nutr Soc 2017;76:478-83.

32. Limperopoulos C, Bassan H, Gauvreau K, Robertson RL, Sullivan NR, Benson CB, et al. Does cerebellar injury in premature infant contribute the high prevalence of long-term cognitive, learning, and behavioral disability in survivors? Pediatrics 2007;120:584-93.

33. Corbett B, Mendoza S, Abdullah M, Wegelin JA, Levine S. Cortisol circadian rhythms and response to stress in children with autism. Psychoneuroendocrinology 2006;31:59-68.

34. Baron-Cohen S, Knickmeyer RC, Belmonte MK. Sex differences in the brain: implications for explaining autism. Science 2005;310:819-23.

35. Sandin S, Hultman CM, Kolevzon A, Gross R, MacCabe JH, Reichenberg A. Advancing maternal age associated with increasing risk for autism: are view and meta-analysis. J Am Acad Child Adolesc Psychiatry 2012;51:477.

36. Iossifov I, Ronemus M, Levy D, Wang Z, Hakker I, Rosenbaum J, et al. De novo gene disruptions in children on the autistic spectrum. Neuron 2012;74:285-99.

37. Hwang SJ, Chen YS. Congenital rubella syndrome with autistic disorder. J Chin Med Assoc 2010;73:104-7. 